\title{
Views of Physical Education Teachers on Values Education
}

\author{
İlyas Görgüt' ${ }^{1}$, Erkut Tutkun ${ }^{2, *}$ \\ ${ }^{1}$ School of Physical Education and Sport, Kütahya Dumlupınar University, Turkey \\ ${ }^{2}$ Sport Science Faculty, Uludağ University, Turkey
}

Copyright $(\mathrm{C} 2018$ by authors, all rights reserved. Authors agree that this article remains permanently open access under the terms of the Creative Commons Attribution License 4.0 International License

\begin{abstract}
Values education is very important for supporting and directing the attitudes and behaviors that brings from birth and changes by the effects of surroundings. The most effective people to provide this support after family are the teachers, especially the physical education teachers who are constantly communicating with the students. Therefore, teachers' perception and knowledge level for this concept should be determined. In order to achieve this purpose, the study was prepared by using qualitative research method. The sample group of the study consists of nine physical education teachers who were determined with easily accessible case sampling method, which is one of the purposive sampling methods. Individual interviews which lasted for an average of 30 minutes were conducted with physical education teachers within the context of semi-structured interview technique. The participants were informed that the interviews would be voice recorded and later their expressions would be written down and after necessary permissions were taken, the interviews were recorded. Descriptive and content analysis methods were used to analyze the expressions which were converted into text. The results of the analyses showed that according to physical education teachers, firstly family and after school teachers are responsible for teaching values. Value education through physical education is necessary and it is considered to be positively reflected in school discipline. It is also stated that in the teacher training programs there should be practical courses for direct values education as well as theoretical courses.
\end{abstract}

Keywords Physical Education, Teacher, Values, Education, View

\section{Introduction}

One of the most important features forming an individual's character and the structure of society is the values individuals have or try to develop. Özsoy (2007) stated that values which have an important role in maintaining the continuity and peace of the society began to attract too much attention in the recent past [1]. According to Aslan [2], a value is generally something adopted, aspired, cared and preferred or something important or valid for people. In addition, abstract measure, which is used for finding out the significance of something, is something's worth, value or the belief about whether something is wanted or not $[3,4]$. Value is the principles guiding an individual's life, a permanent, liked purpose beyond conditions the significance of which can change [5] and sensitivity of individuals about any person, entity, event or situation that can form in moral, cultural, mental, social and universal dimensions [6]. System of values plays a very important role in the lives of individuals, groups and societies and becomes a subject of education. The reason for this is the fact that education is a value-based process and the fact that values exist in every stage of the education process [7]. Thus, education has an important place in conducting activities such as encouragement or development of values.

Education is a social process which includes chosen and controlled environment (especially school) for the realization of an individual's social talent and the development of the individual in the most convenient level [8]. In addition, it is also defined as a purposeful, conscious or unconscious, psychological, sociological, scientific and philosophical process which enables the development of individuals for maximum development and maximum happiness [9]. Plato stated that education developed all the beauties and perfections the body and the soul possessed. In addition, Aristotle advocated that education developed an individual's talents and especially mind, thus an individual can taste the supreme reality, goodness and beauty in which real happiness is included [10]. Kahle (1983)'s argument that values come from the genes and are shaped by people's experiences and Hanssona (2010)'s expressions that people have innate values that they are not aware of [11], brings to mind that values education can be 
useful in developing and progressing an individual's character.

Values education is discussed in various parts of the world within the context of dramatic changes related with the globalization which directly influences human values [12]. Thornberg and Oguz [13] define teaching in terms of values as a moral activity in which teachers consider their moral influences on children and the complex ethic of teaching. The values and morals developed or learned by children within school activities are always called values education. According to Gül [14], values education is discovering and developing the innate positive qualities and reaching an ideal person for a moral society, that is, an individual's gaining cultural, social and universal judgments within a fast developing world and being prepared against different situations. According to Berkowitz [15], it is an initiative within school which includes strengthening young people's academic interest and success and which comprises supporting young people's character and pedagogic skills in order to encourage ethical and positive social tendencies.

As a result of studies conducted in scientific literature and interviews with parents, it can be seen that the authority which has the second greatest influence on the individual after family is school and teachers. According to Taylor [16], governments pay attention to transfer their value codes shared by schooling for the development of young people in the whole world. On the other hand, Aspin and Chapman [17] state that as a result of global fluctuations, social shifts and scientific-technological developments, the changes in value systems are inevitable and thus, greater value crises are expected. According to Nguyen [12], international policy makers and institutions first of all assess what kind of values are on the rise in schools and the society and in the next step; they focus on how to teach these values.

According to Tarman and Kuran (2014) and Akbaş (2004), values education conducted by teachers in school is conducted through both the curriculum and also a latent program [18]. Naturally, this situation brings along the examination of teachers' share in individual's development and teachers' proficiency about values education. However, it is not possible to interview all teachers or to find out the approaches of all branches fort his research. Thus, only physical education branch was assessed. Physical education makes children psychologically, physically and physiologically active. It helps the development of concepts such as character development, decreasing roughness, serving on the basis of group cooperation and young people learn about team work, self-discipline, sportsmanship, leadership and socializing. Regular physical activity provides many healthy and cognitive functions [19]. While physical education lessons develop an individual as a whole, teachers of physical education make more contact with the students, spend more time together and have a more intense interaction and communication with students when compared with the teachers of other branches. Thus, the views of only teachers of physical education were taken in the study to find out the perceptions and knowledge levels of teachers about values education. Cooperation with researchers in different areas and working with a multi-disciplinary mind about values education is of critical importance. Researchers should design the research according to the problem instead of looking for a problem that can adapt to the research design to be used [18]. Thus, cooperation of researchers who are interested in the field and who want to examine the issue with different branches with the teachers of other branches will help to find out the knowledge and perceptions of different branches about the concept and will contribute to the field.

\section{Method}

This is a qualitative research, the purpose of which is to examine the views of physical education teachers about the concept of values education, who are responsible for values education, ability to teach values through physical education and the values that should be in the physical education teacher and the programs. Qualitative research is defined as a type or research which follows a qualitative process to present the perceptions and cases, the data of which are collected through qualitative data collection methods such as observation, interview and document analysis, in a realistic and integrative environment and it has designs such as creating hypothesis, case study and act research [20]. Phenomenology research design was used in the study. Phenomenology is a research method which has specific characteristics of a philosophical content. This method includes the analysis of the individual universe, that is, individual experiences, individuals' perceptions and the meanings they allocate to these [21].

\subsection{Study Group}

Easily accessible sampling method, which is one of the purposive sampling methods, was used to choose the sample. This method saves speed and practicality since it chooses the situations which are close and accessible to the researcher [20].

Table 1. The demographic disturbance of the participants

\begin{tabular}{|c|c|c|c|}
\hline Gender & School & Age & Experience \\
\hline \multirow{4}{*}{ Female } & Secondary & 31 & 3 \\
\cline { 2 - 4 } & Secondary & 34 & 4 \\
\cline { 2 - 4 } & High & 37 & 10 \\
\cline { 2 - 4 } & Secondary & 36 & 12 \\
\cline { 2 - 4 } & High & 39 & 14 \\
\hline \multirow{4}{*}{ Male } & High & 33 & 4 \\
\cline { 2 - 4 } & Secondary & 36 & 11 \\
\cline { 2 - 4 } & High & 39 & 15 \\
\cline { 2 - 4 } & High & 42 & 19 \\
\hline
\end{tabular}




\subsection{Data Collection Process}

Semi-structured interview technique was used to evaluate physical education teachers' views about values education. While preparing the questions for teachers who participated in our study, existing information in literature was collected and a question pool was created. For content and structure validity of the questions, the questions were checked by experts and the necessary edits were made and it was decided to ask 8 questions. The teachers were first informed that the interviews would be voice recorded, these records would be kept by the researcher and other people would not be able to reach them and later on, these recordings would be transcribed and analyzed. After a comfortable environment was provided and necessary permissions were taken, the interviews were made face to face with a voice recorder. The interviews lasted for an average of 30 minutes. The questions in the study are below:

\subsection{Data Analysis}

The interviews recorded by the researcher were computerized. The teachers were coded as T1, T2, T3, T4, T5, T6, T7, T8 and T9 through Maxqda statistical program, the texts were analyzed descriptively and in terms of content. The content analysis was used to transform the descriptive contents into a form that the reader can understand. Firstly, teachers' opinions about values education were interpreted and coded. As a result of these coding, similar expressions were gathered around certain concepts. In order to support these coding and to increase the reliability, direct citations were given.

\subsection{Data Collection Process}

Semi-structured interview technique was used to evaluate physical education teachers' views about values education. While preparing the questions for teachers who participated in our study, existing information in literature was collected and a question pool was created. For content and structure validity of the questions, the questions were checked by experts and the necessary edits were made and it was decided to ask 8 questions. The teachers were first informed that the interviews would be voice recorded, these records would be kept by the researcher and other people would not be able to reach them and later on, these recordings would be transcribed and analyzed. After a comfortable environment was provided and necessary permissions were taken, the interviews were made face to face with a voice recorder. The interviews lasted for an average of 30 minutes. The questions in the study are below:

Question 1: Could you briefly describe the values education?

Question 2: Who has the primary responsibility for teaching values?

Question 3: What do you think about teaching values through Physical Education? How does this reflect to school discipline?

Question 4: If we want to make a program through physical education and sports, which values should this program primarily aim to provide?

Question 5: What way do you follow when you try to make any value for the student?

Question 6: What should be the basic values that Physical Education teachers should have?

Question 7: What do you think about the knowledge level of PE teachers' values education?

Question 8: Have you ever meet any lessons or application for value in the undergraduate programs that educate physical education teachers, or which courses and practices should be for values education?

\section{Results}

Under this section, the answers obtained from questions asked to teachers are given in categorical charts obtained from the statistics program. The participants were asked 8 questions with semi-structured interview and descriptive and content analysis were used.

The question "Could you briefly describe the values education?" was asked to teachers of physical education who participated in the study. 


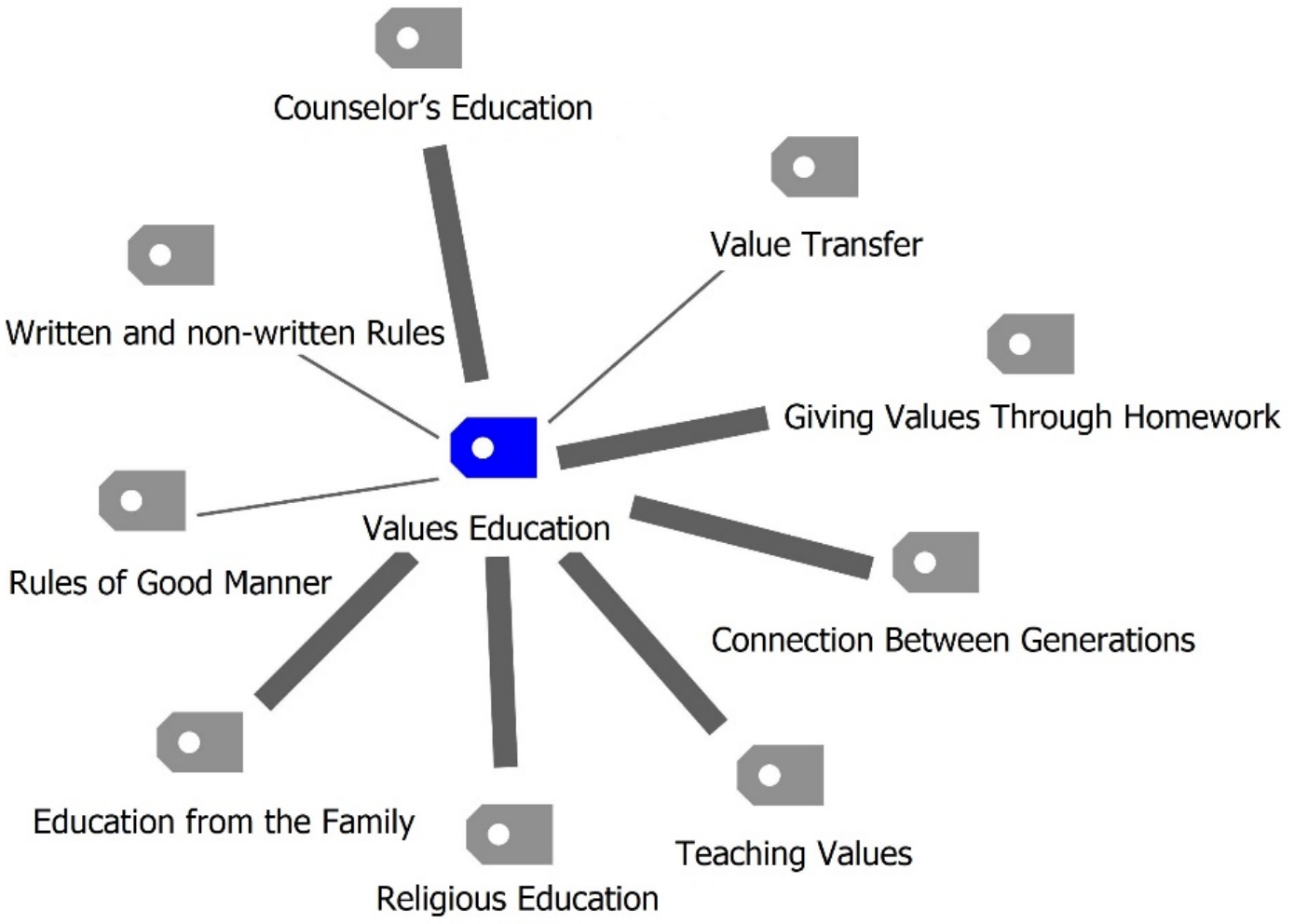

Figure 1. Physical education teachers' expressions about the definition of values education

Teachers of physical education in our study defined values education as a connection between generations, transfer or teaching of written and non-written rules or values from the past, and teaching the rules of good manners by the family. According to teachers' activities of counselors is also values education. In addition, it can be seen that a method used frequently by physical education teachers is teaching values through homework. Some of the answers of teachers to the question are given below.

T1: We call the practices of individuals in society which are specific and which can help them express their specific behaviors, structures and thoughts and I believe that the transfer of these values which differ from society to society to students and teaching these values to the society is values education.

T3: Values education is the transfer of the concept of value, which I just mentioned, to the generations which will form the society, that is, the transfer of values to next generations by making a connection with the society.

T6: The national, moral values and responsibilities we get from the society, these are the values education.

T8: It is giving children values such as love, respect and morals and continuing this education at school.

T9: We can call them as the rules of good manners which people have to follow so that they can live together and for the welfare of the society. In other words, we can call them respect and tolerance. They are written and non-written rules individuals have to follow so that they can grow healthily.

The question "Who has the primary responsibility for teaching values?" was asked to teachers of physical education who participated in the study. 


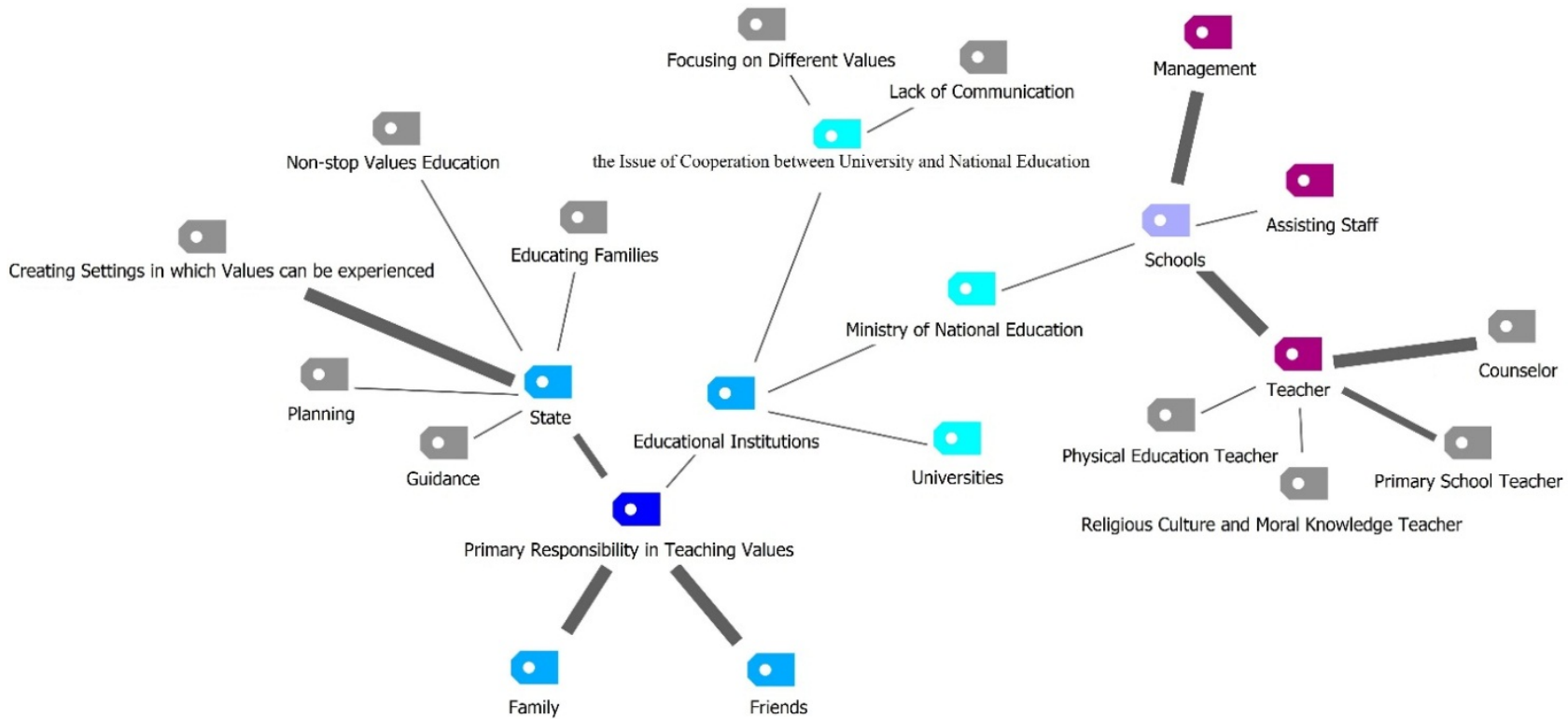

Figure 2. Physical education teachers' expression about the primary responsibility in teaching values

According to the physical education teachers in the study, particularly the state and also the family, friend environment and the education institutions the child is in are primarily responsible of values education. The state is responsible of planning and directing, while the family is responsible of education and creating environments in which the values obtained can be experienced all the time. In educational institutions, school managers, assisting staff, physical education teachers, counselors, primary school teachers and religious culture and moral knowledge teachers. In addition, teachers consider universities as another field of responsibility. However, the lack of communication between the university and the ministry of education and the fact that different values are focused on create cooperation problems and decrease the efficiency of some values education. Some of the answers of teachers to the question are given below.

T1: Since responsibility starts in the family in education, I think that it starts in the family here, too. Yes, I will teach the student about the subject in values education, however, the child should also come with a specific structure.

T2: Primarily, the family. The family is in the basis of all of the educational process of the child. Since the child spends most of his time with his parents and siblings until the age of 5-6, family comes first. I think immediate surroundings come next, such as neighbors and relatives. Following this, I can list teachers, the streets, which is the outer environment. Within the school, it is possible to list school management, school counselor teacher, physical education teacher, primary school teachers, other teachers and other school personnel, within the authority given by the ministry of national education.

T4: State is primarily responsible in transferring values, the state should not forget about education. The state should direct and plan education well. In transferring values, the state is followed by teachers and then universities. However, there is a great disconnection between universities and national education. National education and universities try to infuse different, even contrary values. We should think about primary school, secondary school, high school and university as a whole and there should be cooperation between all of these. They should not conflict with each other.

T5: It is the family. At school, it is the teachers. I believe that everything starts in the family. The better the child comes from the family, the easier is our job. At school, the counselor and the school manager are seen by everyone. However, primary education teachers and branch teachers are always in the background.

T7: In values education, we should include the mechanism which includes the teachers, directors, students and parents. When there is communication between these two important institutions, we are already contributing to values education. In a listing within the school, primary school teachers come the first. For students in secondary school, I believe that ranch teachers, especially physical education lesson can make contributions.

The question "What do you think about teaching values through Physical Education?" was asked to teachers of physical education who participated in the study. 

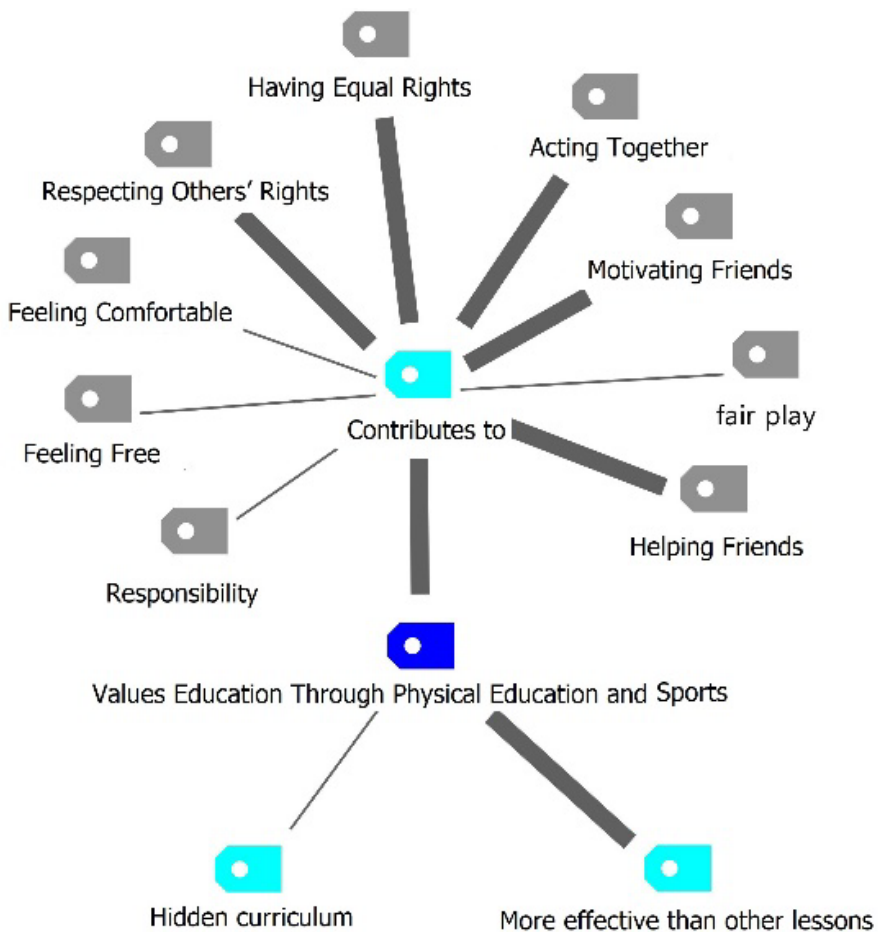

Figure 3. Physical education teachers' opinions about teaching values through physical education

According to the physical education teachers who participated in the study, teaching values through physical education contributes to personal development. According to teachers, the lesson gives students characteristics such as acting together, motivating friends, fair play, helping friends, responsibility, feeling comfortable and free, respecting others' rights and equality. In addition, teachers consider their lesson more prioritizes than the other lessons, and they advocate that values are taught within hidden curriculum, though not directly. Some of the answers of teachers to the question are given below.

T2: I believe that such a thing certainly exists in physical education lesson. A student helping a friend get up when he falls is fair play, tolerance. The behavior of a stronger student encouraging his less talented friend during a competition by saying "yes, you can do this", all of these are in fact within the physical education lesson.

T3: I certainly believe that they are taught through physical education. For example, ceremonies, exercises for organization. Exercises for organization enable children to realize that they need to respect others'rights and enable them to react directly to given commands. This is also valid for other sport branches. In a definition, sport is described as a discipline. Thus, wearing the same things, starting and finishing together, hygiene, having equal rights, and respecting others' rights are all features which develop in physical education and sport settings.

T4: Individuals should first of all repeatedly experience a value so that they can have this value. One of the most important lessons that can enable this is the physical education lesson. It is a lesson in which students feel comfortable and free, teachers have the opportunity to communicate closely and individually with children and the lesson has an impact on children. Thus, I believe that teaching values in physical education lesson is very important.

T6: In physical education lessons, we teach students to ask for permission while taking a friend's turn, to help a friend when he is injured during a competition, to speak of an injustice and to tell the truth, to thank people and to apologize when they are wrong.

T8: During the lesson, I make the students build a track, then make them undo the track, then I make them build it again. Thus, I give the students the message that they can rebuild things they break down. I try to teach them not to speak ill of their friends and not to lie, I try to encourage them to do the right things and goof things. Not only physical education teachers, all teachers are responsible for values education in their lessons.

T9: Our lesson is really important. During education, we contribute to values education with the association between winner and loser, and through practices such as ethics and fair play. That is, values education through physical education can be a correct expression.

Physical education teachers were also asked the question: "How does teaching values through Physical Education reflect to school discipline?" 


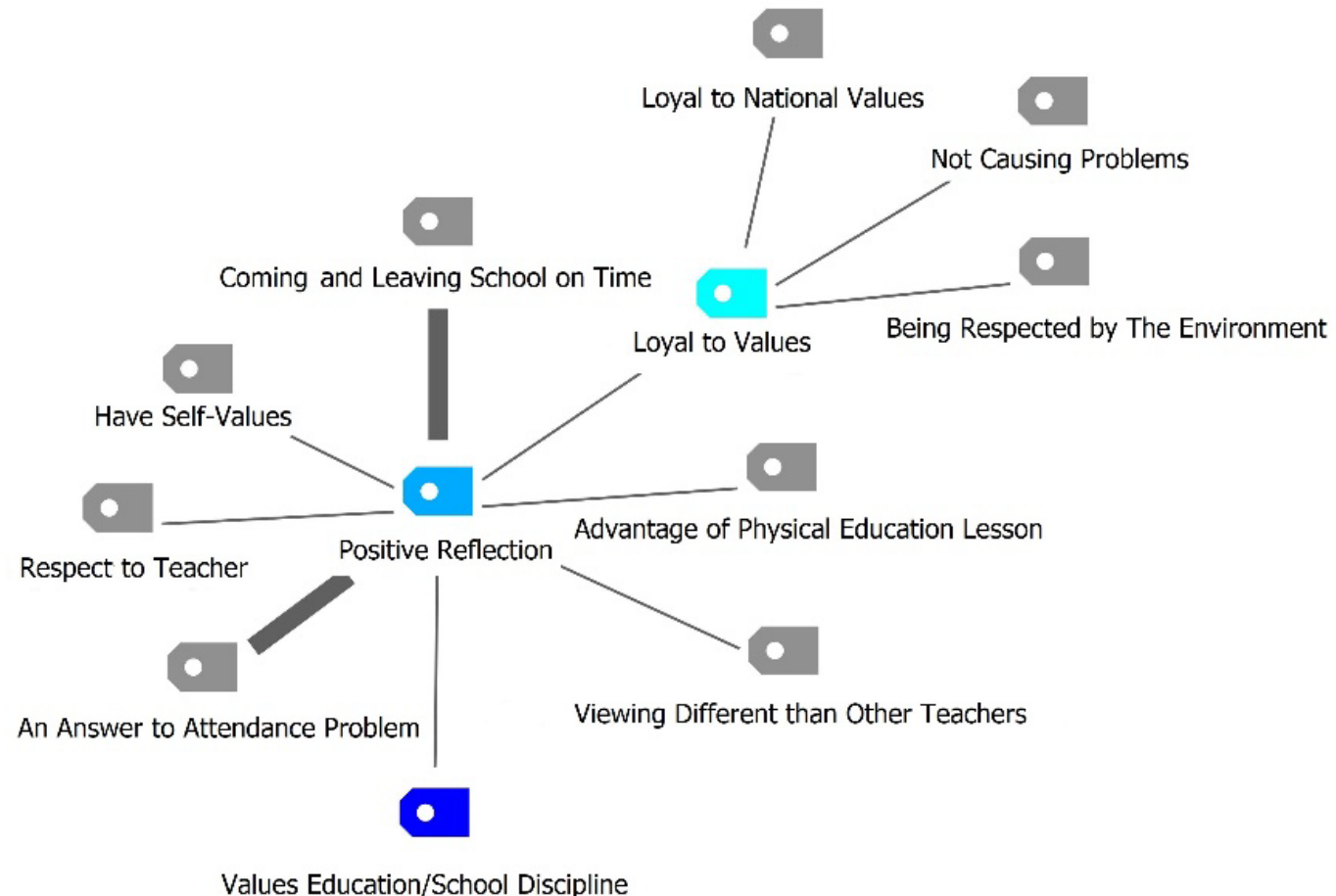

Figure 4. Physical education teachers' values about the reflection of values teaching on school discipline

It was stated that teaching values would have a positive effect on school discipline since students view physical education teachers differently from the teachers of other lessons. According to the teachers who state that the lesson is an advantage to them, through suitable education, problems such as attendance, respecting teachers, coming to school on time will be solved. In addition, it is advocated that an individual who is loyal to his self-values and national values will form a positive identity and won't cause problems. Some of the answers of students to the question are given below.

T1: Although our lesson is considered to be inferior to other lessons, it is considered as prioritized among students. A student's saying "good morning" to me, although he doesn't greet other teachers, reflects his attitude towards me. Teachers are effective; however, we start 1-0 ahead with the advantage of physical education and create a different communication. This situation, in turn, reflects positively to school discipline.

T2: In terms of its reflections to school discipline, one of the lessons which have an effect on solving the attendance problem is physical education because students love this lesson and they wear their sportswear happily. Thus, it is easier to teach values in these lessons. In terms of being careful about time, solving problems about coming to school and leaving, having equal rights with friends all have a positive reflection on school discipline.
T3: It is reflected $100 \%$ positively on school discipline because the values taught are important for us adn they are all positive. A value has a positive meaning, when we practice that value, no one is hurt and we are respected and appreciated by people. A child who is loyal to family values and national values is respected by his environment and does not create problems because a child who has a place in school won't show negative behaviors in order not to lose this place.

T5: There are also responsibilities in values education; we teach responsibility by giving assignments to students. For a student who knows his responsibilities, it is enough to know the rules, he will obey the rules. If a person has self-values, if he has got values education, and if he has self-respect above all, this will be reflected positively on school discipline and there won't be a need to make extra rules and to punish students. What matters is to teach that responsibility and consciousness.

T7: When we teach values appropriately, it will be reflected positively. There will not be undisciplined acts. There are very serious problems about morals these days, thus, if we teach values appropriately, this will be reflected on the behaviors.

The physical education teachers who participated in the study were asked the question "If we want to make a program through physical education and sports, which values should this program primarily aim to provide?" 


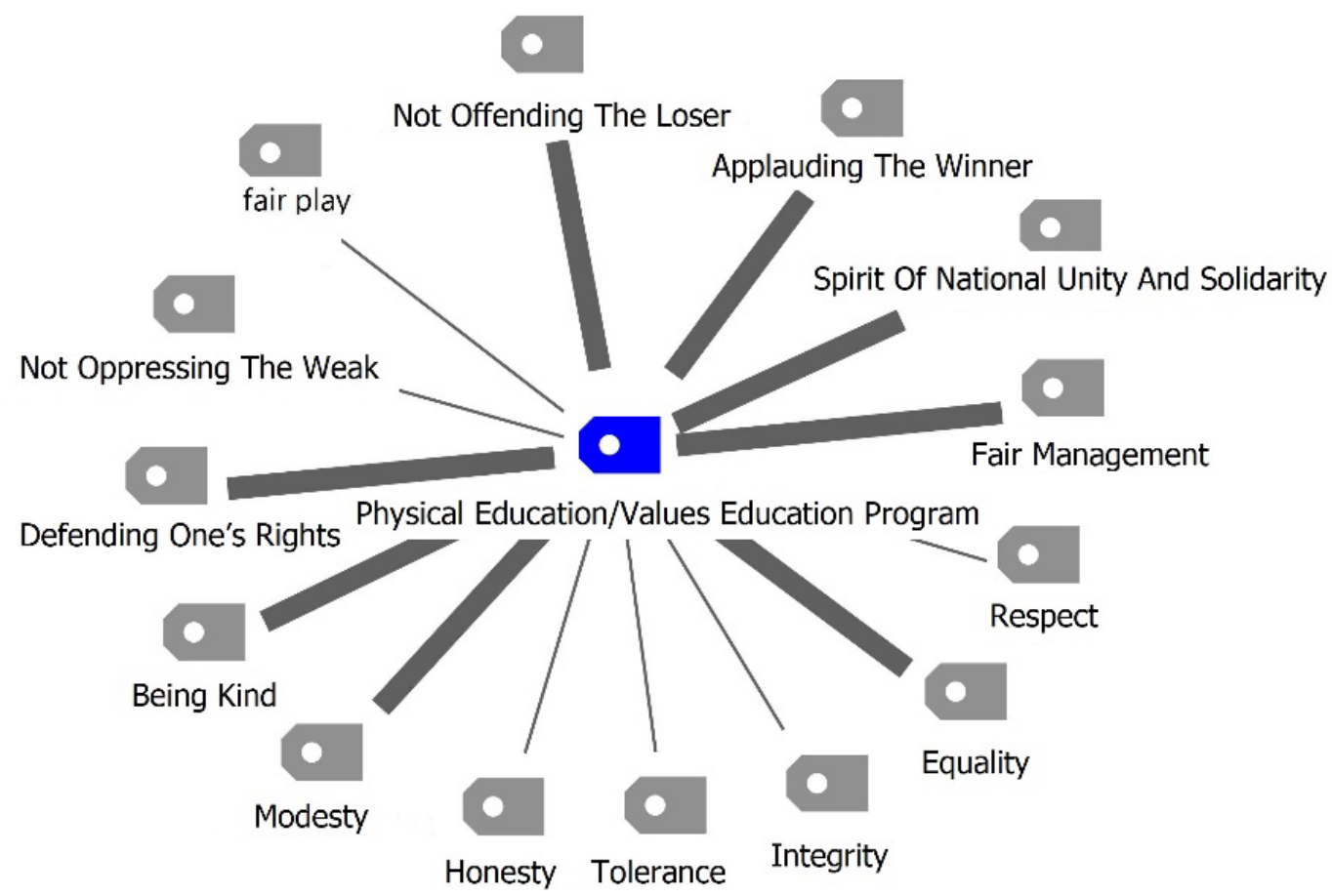

Figure 5. Physical education teachers' opinions about which values education programs should teach

When physical education teachers in the study were asked about which values they would include in a program they were asked to prepare, they stated that they would include values such as modesty, honesty, respect, equality, defending rights, national unity and solidarity, congratulating and not offending the loser, fair play and not oppressing the weak. Some of the answers of teachers to the question are given below:

T3: First of all, honesty, understanding, tolerance, integrity, fair play, respecting others, not oppressing less talented students, but first of all, honesty and integrity should be taught, the others will follow.

T4: If a program was to be made, first of all spirit of national unity and solitary, respecting each other, equal rights, fair management should be taught since a generation with national and spiritual values is needed for a nation to survive. I believe that these values can be taught easily through physical education lesson. Fair play and gentlemanship taught in physical education lesson should also exist in the society. It should exist in the street, at home, at playgrounds. Respecting the opponent, applauding the opponent when beaten, not being over enthusiastic both as a loser and as a winner are things that can be taught through sports. Physical and psychological strength can be obtained through physical education.

T7: Our peoples' values in the past and our religious values should certainly be taught. We should protect national and religious values and teach them with the programs.

T8: Morals first. Order, respect, not lying and discipline are important. It is not reasonable to expect the same performance from all students in the physical education lesson; thus, their moral and value development should be on the forefront. Being respectful and honest, that is, moral teaching is important.

T9: There should be love. When there is love, there will be respect and when there is respect, there will be morals.

The physical education teachers who participated in the study were asked the question "What way do you follow when you try to make any value for the student?" 


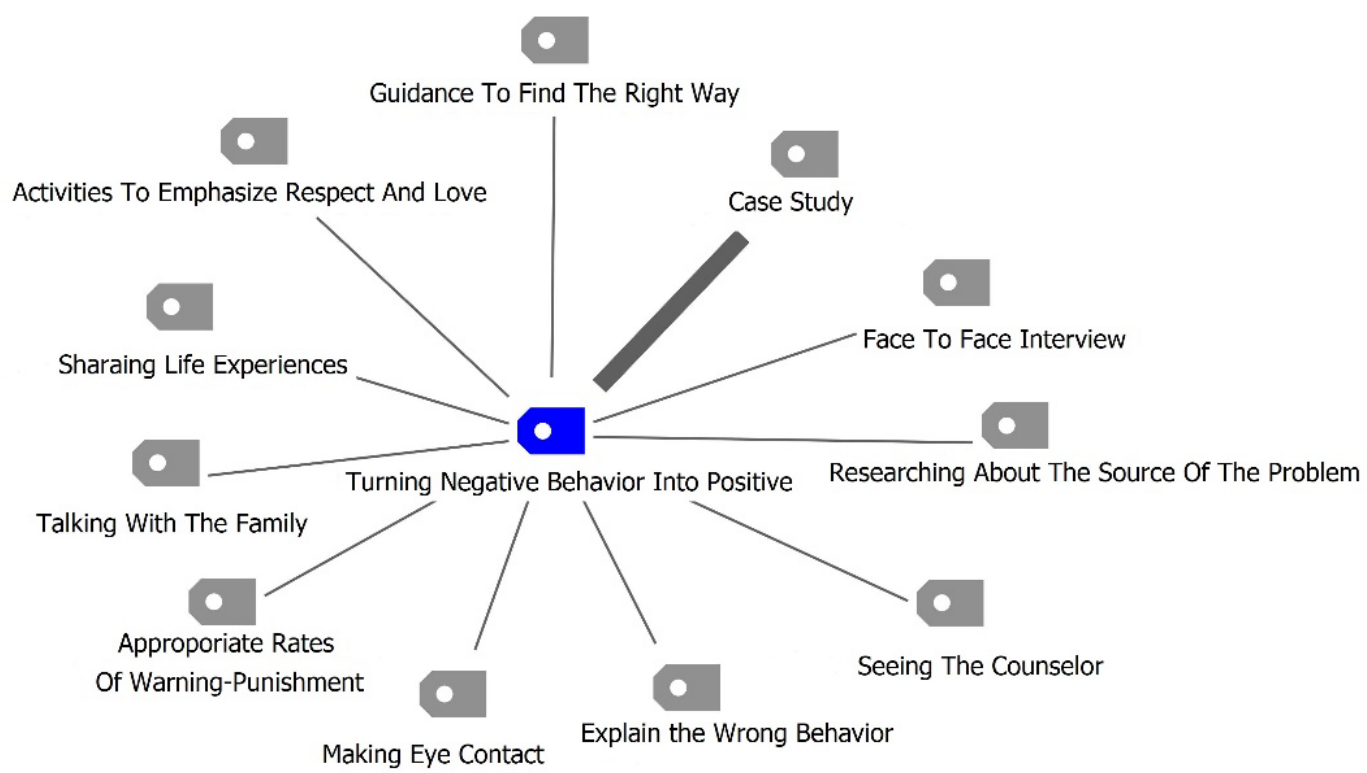

Figure 6. Physical education teachers' opinions about teaching positive values

Physical education teachers in our study stated that when they wanted to turn a negative situation they observed in the student into a positive one, first of all they researched the source of the problem and tried to find out whether this problem was caused by the family or something else. Following these, they resort to methods such as eye contact, face to face talks, showing the right thing, showing examples, transferring experiences, organizing activities to bring out love and respect. When teachers cannot find a solution to the problem, they cooperate with the family and prefer to get help from the counselor or get psychological help. Some of the answers of teachers to the question are given below:

T1: First, I talk to the counselor about the student's problem. Does the student have a problem with the family? I look at the family structure first. I do not give advice in public, I talk face-to-face with the student and try to speak as an older sister. Even if I am speaking in public, I tell a good story or event without giving the student's name. This way, I reinforce something right.

T2: I bring respect to the forefront by telling them they have to prioritize love and respect, and by telling them that everyone has to show respect to each other since we share the same environment. I tell them that love has to be prioritized for people to be happy and willing somewhere. I tell them that if there is no love, they will come to school unwillingly, they will frown, they won't get any pleasure and they won't get any satisfaction, no matter what their job is. I asked them what their facial expressions, behaviors, wishes were like when they were doing something they liked. As a result I tell them that they need to love the school and they should prioritize love and respect to provide positive motivation for each other. Through this education, my students have unity and solitary in class.

T4: If we want to teach values to a person, first of all we should tell them that their behavior is wrong. How can an individual change himself? If he wants to. For example, imagine that you are a smoker. No one can change this as long as you don't accept that it is bad. I believe that first of all the child should be told about the things that might hurt him and the problems he might encounter. You can't do this by punishing. When you directly punish a child by telling him that he lied, the child will continue to lie since he doesn't know what he is being punished for. He needs to know what is right in order to change. Thus, first of all, we should tell the child what wrong behaviors are.

T7: In the classroom, I make the student understand his mistake by making eye contact with him, without offending him. Sometimes it may be necessary to talk one to one. You can talk to the child, inform him about his mistake and make him fix this mistake.

The physical education teachers who participated in the study were asked the question "What should be the basic values that Physical Education teachers should have?" 


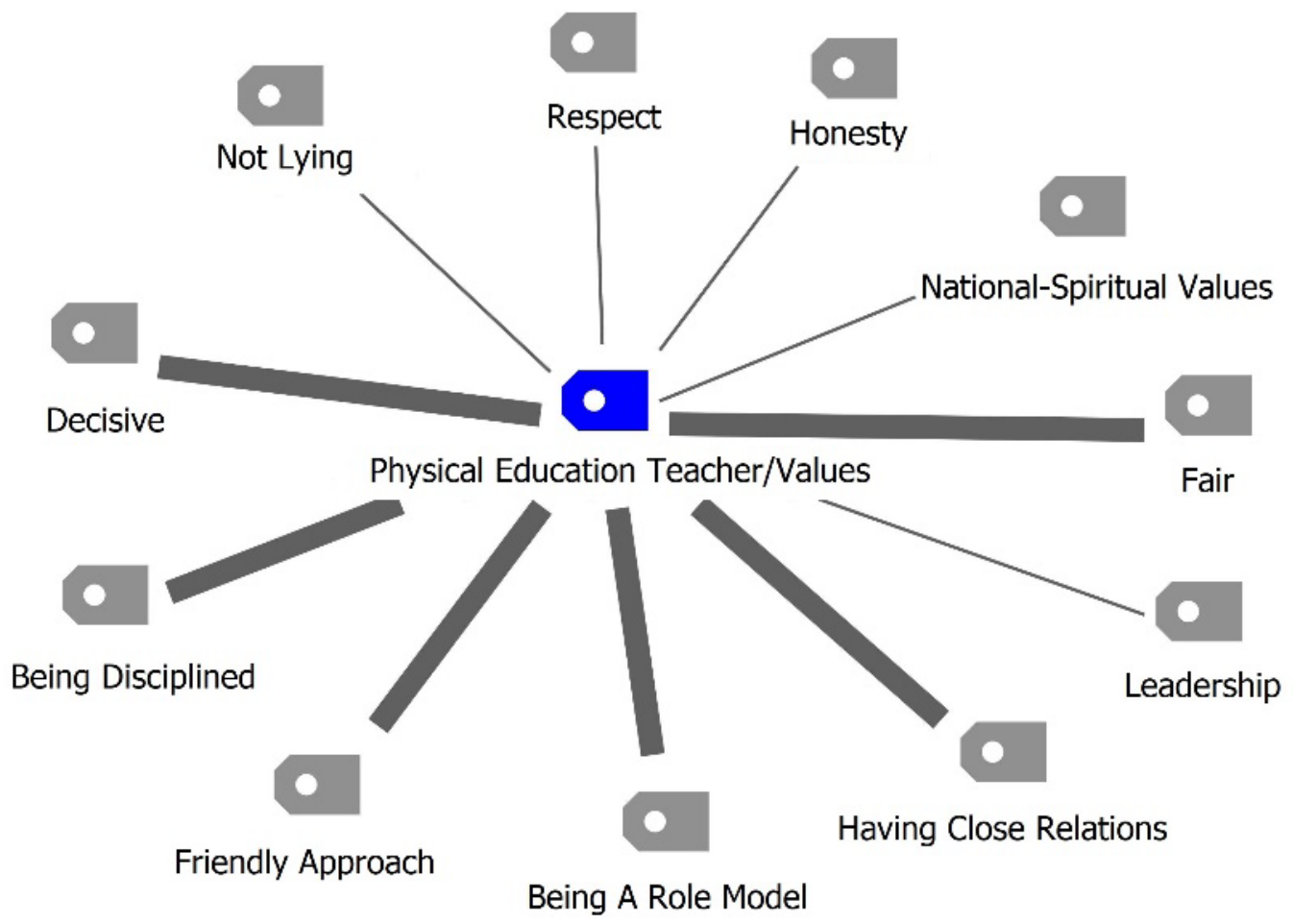

Figure 7. Physical education teachers' expressions about the basic values they should have

Physical education teachers in the study stated that a teacher should have qualities such as being a role model, not lying, being fair, having close associations, friendly approach, having national-spiritual values, being disciplined, being decisive, being a leader, being honest and respectful. Some of the answers of teachers to the question are given below:

T1: I certainly think that discipline is the foremost, the others will follow discipline. Let's both have fun and do these within rules. When there is an environment of laughing, having fun and being friendly, students can sometimes misunderstand and use this. However, if there is discipline, the others will follow. There should be basic values such as discipline, being friends, having close associations, setting an example, being a role model.

T2: The characteristic leadership is a feature a physical education teacher should have because gathering such people together, moving them with only a command and doing something sudden with this group requires qualities of a leader. In addition, teacher should be fair and loving, should be a good role model, be decisive and have communication skills.

T5: Should have national and religious values, that is, the love of country and nation. Young people should also be loyal to their religion. Honesty is very important, they should not lie. They should respect elders. These features should certainly exist in a physical education teacher.

T7: Should have a good character, should not lie, should have sufficient knowledge of the field, should communicate well with the society, since teachers sometimes be psychologists, drivers, etc.

T8: Should be honest and moral, should not lie, and should be respectful. If I tell the child not to spit, but we do spit, it won't be a correct thing. That is, we should act the way we expect children to act, we should e role models.

T9: In terms of teachers, teachers should not tell the students to be respectful, to talk appropriately, but show these with acts. Teachers can set examples to children with the way they talk to each other. Teachers cannot expect the students to tell the truth when they are not telling the truth that is, we need to be role models. In addition, teachers should be able to take part in any organization and to direct it, that is, they should have leadership skills. I believe that we should have humane values such as being honest and moral.

The physical education teachers who participated in the study were asked the question "What do you think about the knowledge level of PE teachers' values education?" 


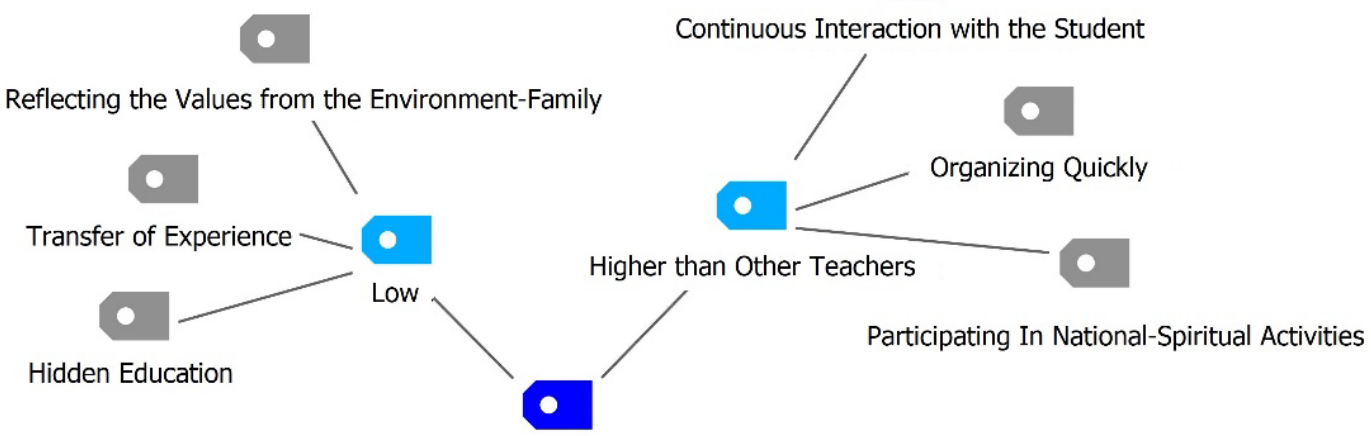

Physical Education Teacher/Value Knowledge Level

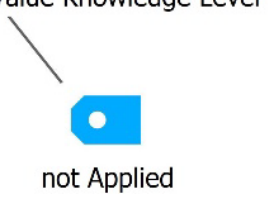

Figure 8. Expressions about physical education teachers' level of knowledge on values education

According to some of the physical education teachers in the study, teachers' level of information about values education is not sufficient. According to some teachers, there are teachers who have no knowledge about values education and who cannot practice values education. Some teachers stated that they had a low level of knowledge about values education, they did not teach values directly and they transferred knowledge from the environment or the family. In addition, teachers advocated that they transferred their experience and they already taught values implicitly in the program. Among teachers, there is a general view that they have higher values education levels since they are within a continuous interaction with the students, they can organize quickly and they are within national-spiritual activities all the time. Some of the answers given by teachers are given below.

T1: Generally, they are not applied. Actually, it changes from teacher to teacher. I believe that I do apply. However, in general, I don't think that teachers apply values education concept much in Turkey.

T2: ...I did not encounter values education approaches for physical education teachers only. The fact that physical education and sports teachers' have high levels about values education when compared with other teachers since they are always within national-material activities and since they can organize quickly and act collectively.

T4: I think our level of information is not very high. Students are not taught as well-equipped in our school about values education; if the family does not teach values, not many people are well-equipped. I believe that the teachers, including me, do not have a very good level of information. They try to reflect the values they get from their environment and their family.

T5: I think physical education teachers are very high in terms of values education. During a competition, holiday or ceremony, we transfer some values to students consciously or unconsciously. I believe that although physical education teachers do not have the exact knowledge about values education, they are very, very high in application.

T6: I don't think that the old teachers are very proficient. No one undertakes the job of teaching children values theoretically. Although we have some information on this issue due to KPSS and formation, I don't think that teachers are proficient about this concept; I even believe that we cannot find the meaning of the word and teachers who cannot define this concept.

T9: I think that physical education teachers have moderate level of information about the issue of values education. I personally think that I have information.

The physical education teachers who participated in the study were asked the question "Have you ever met any lessons or application for value in the undergraduate programs that educate physical education teachers, or which courses and practices should be for values education?" 


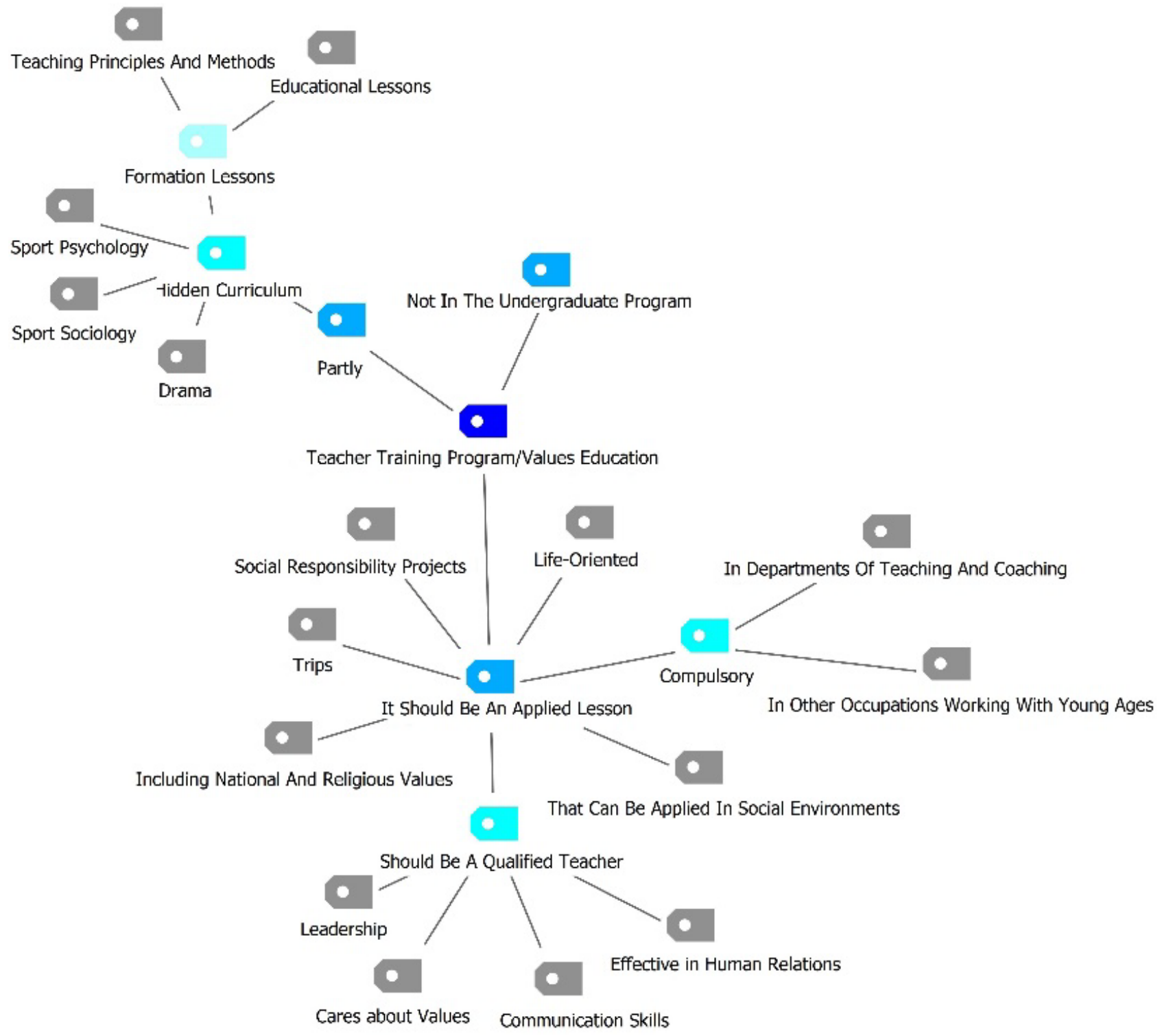

Figure 9. Expressions about course/application status of physical education teacher programs.

According to some physical education teachers in the study, hidden values education is conducted through formation lessons and some sport lessons. Physical education teachers stated that there should be a course with both theoretical and application parts under the name values education and all teachers teaching small age groups, mainly departments of teaching and training have to have this course. According to teachers, there should be trips and social responsibility projects in applied courses, the course should include national and religious values and be life-oriented. The values should be taught through teachers who are effective in human relations, who have high communication skills, who care about values and have leadership characteristics. Some of the answers of teachers to the question are given below.

T3: Although I cannot remember exactly, I guess we had it in teaching methods and techniques. There should be such a course. It will be more useful to give students a subject at internship practice courses and to tell them which subjects to teach and video record and ask them to tell what they did in class because I believe that applied courses will be more permanent.

T5: Although such issues were addressed in our formation classes, sport psychology and sociology courses, we did not have a course named values education directly.

Rather than theoretical lesson, an application-oriented values education in social environments should be taught. I believe that teachers who have leadership characteristics and communication skills, who attach importance to values and who are effective in human relations should take part in teaching this course.

T6: We did not have any courses. It should be a separate course that can teach national and religious values 
together. If it is just on paper and if you want this to be taught in every lesson, problems will occur about application and subjects will be taught superficially. Values should be taught especially in departments of teaching and training because they are very important since they take care of small children. It should not be limited to only teachers and training, other occupational groups which take care of small children should also have values education.

T7: There is no direct lesson for values education; however, they can be found in teaching formation courses. It should be an applied lesson since it is an applied lesson and since we prefer teaching by doing, living, organizations and visits to non-governmental organizations or old people. Within school, it can be a course with applied and theoretical information.

T8: We did not come across any applications. However, there can be a course with theoretical parts and application parts which can show wrong behaviors to students with drama management.

\section{Discussion and Conclusions}

In this part, the views of values education system are assessed in the light of research findings and literature. Physical education teachers were asked to define the concept of value education and they defined this concept as transferring or teaching past experiences and values to new generations, that is, building a connecting between generations, and teaching the written or unwritten and necessary rules of good manners from the past within the family. Some of the teachers show value education as an activity school counselors do or have to do. Physical education teachers state that they frequently resort to homework method to teach students values.

According to physical education teachers, mainly the state and then family, friends and educational institutions have primary responsibilities. The state should plan and lead and contribute to the creation of more conscious families with family education. It is also the state's duty and responsibility to create the environment to experience the values gained continuously. When schools are considered, it is thought that school managers, assistants, teachers of physical education, counselors, primary school teachers and teachers of religious culture and moral knowledge have important roles about value education. In addition, teachers considered universities as another field of responsibility. However, focusing on different values due to lack of communication between university and the ministry of education creates a problem of cooperation and decreases the efficiency of values education.

In values education, although the family is considered as determinant, it should be considered as the primary duty of schools due to value conflicts experienced at schools [22].
Acun et al. (2013) argue that the behaviors and values acquired by children at a young age will influence their future; thus, primary education plays an important role in acquiring values. They state that the primary duty in teaching these values falls to schools and families. Cooperation of the school and the family requires a sacrifice needed in observing and monitoring children and teaching them values [23]. According to Çengelci et al. [24] values or gaining values is a process that needs to be followed together by the school and the family. Schools try to teach students values such as love, respect, tolerance, cooperation and responsibility. Teachers state that there is a communication between the related partners in the school and students based on respect. In addition, it is said that teachers prioritize the teaching of values mentioned in the open and ended programs. Çelikkaya and Filoğlu [25] state that for teachers, families and teachers come first in the teaching of values, followed by the environment, school and other factors. In a study conducted with primary school teachers, Ylldırım (2009) reported that teachers thought values should be taught first in the family, then in schools [26]. Balc1 and Yanpar Yelken [27] stated that teachers included value education in social sciences and Turkish lessons the most. According to Hadi [28], teachers of religion and citizenship education and counselors have responsibilities in the teaching of personality values. However, activities about the teaching of values should also be conducted by all teachers teaching different subjects.

In the light of our results and the studies in literature, there should be a strong cooperation between school and the family in the value education given to individuals. It is thought that a more effective values education can be provided with the state providing suitable conditions.

Teachers of physical education in the study believed that teaching values through physical education will contribute to an individual's development. According to teachers, since the lesson teaches students to act together, to motivate friends, fair play, helping students, responsibility, feeling free and comfortable, respecting others' rights and equality, it is more effective about values education. In addition, teachers consider that their lesson is more in the foreground when compared with other lessons, and advocate that values are taught within hidden curriculum, if not taught directly. Again, the teachers stated that teaching values through physical education will have positive reflections in the school discipline because physical education lesson and the teachers of physical education are put in a different position than the other lessons by students. According to the teachers who said that the lesson provided them an advantage, the most important problems of today's education system, including absence, respecting teachers, coming to class on time and leaving on time will be solved through an appropriate education. In addition, it is also advocated that an individual who is loyal to his self-values and national values will be respected by his environment, 
form a positive identity and not cause any problems. Çengelci et al. [24] stated that values education should be included more in education programs and it should be made easier for teachers to allocate time to values in educational activities. Thus, a more intense values education by the teachers of physical education and other branches and with the time and material support of education planners, it is assumed that student based problems in the education system can be solved.

Teachers of physical education stated that in a program which will teach values through physical education and sport should include values such as modesty, honesty, respect, defending the right of equality, national unification, congratulating the winner, not offending the opponent, fair play. Memişoğlu [29] reported that teachers placed emphasis on the values in education programs; however, they placed more emphasis on values such as patriotism, respect for thoughts and ideas, and responsibility. As can be understood, teachers of physical education prefer that national and non-material values should cone before values about competition or sports activities in the program. Organizing the programs by taking these into consideration will provide important attainments both for students and for athletes.

Teachers of physical education stated that in order to turn a negative situation they realized in the students into a positive situation, first of all they researched the source of the problem. They reported that they did not directly target the student, but resorted to methods such as eye contact, telling an example, transferring experiences, and organizing activities to put love and respect on the forefront. If the negative situation still continues, they resort to methods such as talking to the student and then trying to make the student find the right behavior by setting off from the wrong behavior. When the teachers cannot solve the problem, they prefer cooperating with the family, getting help from the counselor or getting psychological help.

Kurtdede Fidan [22] reported that prospective teachers suggested being a role model, using expressions to encourage values, increasing students' awareness, telling stories about values, and activities which have a dimension of values such as cinema, TV film and theatre in teaching values to students. Çelikkaya and Filoğlu [25] concluded that teachers had important duties in teaching values and thus teachers had to e a good role model to students. In addition, in teaching values to students, activities such as emphasizing the subject in the lesson, being a model, associating with contemporary events, performance homework and using material should be included more. According to Memişoğlu [29], being a model is the primary method used by teachers in values education. Teachers state that the suggestion approach helps transferring in a short time the information that the teacher wants to transfer to the student, and in addition they stated that they did not have enough information about the other approaches. In addition, in terms of activities, teachers make use of activities such as group work through case studies, telling stories or completing stories, trips, drawing, and extracurricular group works. According to Balc1 and Yanpar Yelken [27], for teachers learning through case studies, being a model, problem solving, developing rules and cooperative learning are the most effective methods in values education.

Teachers have a great role in turning negative situations into positive ones. When approached in a wrong way, undesired situations can occur such as reinforcing a negative situation. Thus, being a good role model and a suitable approach can provide important attainments in solving problems.

Physical education teachers advocate that a teacher should have qualities such as being a role model, not lying, being fair, forming close relationships, being friendly, having national and non-material values, being disciplined, being decisive, being a leader and being honest and respectful. Balci and Erdeveciler [23] stated that sport authorities thought people should have values such as dignity, tolerance, communication, love, sharing and effort; however, there were some problems in transferring such values.

Results of studies which were conducted to determine physical education teachers' levels of information about values education show that teachers do not have enough information about values education. Teachers state that they teach values indirectly by transferring the values they get from the family and the environment. Some teachers state that they have higher levels of values education when compared with other teachers since they are within an interaction with the students all the time, they organize quickly and have intense national and non-material activities although they haven't taught values directly.

Kurtdede Fidan [22] found that prospective teachers did not have enough level of information about values and values teaching. Çelikkaya and Filoğlu [25] stated that teachers are insufficient about values teaching. Thus, planning and conducting trainings to increase teachers' level of information will be helpful for teachers in developing positive perceptions about this concept and in using the concept more effectively.

Teachers of physical education stated that they did not get any lessons about values teaching in their undergraduate program and added that values were taught through a hidden curriculum through formation lessons and some sports lessons. According to teachers, there should be a lesson of both theory and practice under the name values education. The lesson should be life-oriented, it should include national and non-material values and the students should be able to maintain the values they acquire. In addition, they stated that the lesson for values education should be compulsory for the departments of physical education and sport teaching and coaching training and all branch teachers who teach small age groups. In addition, it 
is recommended that the lesson should include social activities such as trips and social responsibility projects and to carry on within a game format. Teachers express their ideas that if teachers who will teach values will be effective in human relationships, have high communication skills, care about values and have leadership skills, the efficiency of education will increase.

Kurtdede Fidan [22] reported that prospective teachers did not have any education about values and values education. Çengelci et al., [24] stated that values education activities should be prepared on the basis of the classroom and student-centered, they should be based on application and the school environment should be made suitable for values education. Çelikkaya and Filoğlu [25] advocated that programs are insufficient in values education since teaching is on the forefront in the curriculum, students are indifferent and lesson hours are insufficient. Beldağ [18] found that due to anxieties about time, there are few studies which consider philosophical basis and approach the presence of values education with a critical approach. He also recommends that more post graduate and especially doctorate studies should be conducted in the field, theses should be designed well methodologically and post-graduate students should be more equipped about research methods and statistical information. It is thought that teaching students about values in their undergraduate education and forming the curriculum and programs in line with these will support future teachers or trainers to be more equipped.

As a conclusion, teachers of physical education interpret values education as a body of written and unwritten rules transferred from generation to generation. According o teachers, values education is under the responsibility of a structure consisting of state, family, school and environment. Great duties fall on teachers within this structure. Teachers of physical education advocate that since the lesson is loved by students and they are continuously interacting with students, physical education lesson will provide great in values education and will be reflected positively in school discipline by finding solutions to many problems in today's education system. According to the teachers, students, especially undergraduate students need an applied values education lesson. Teachers also stated that in case of a values education program for physical education, this program should be based on national and non-material values and also sportive values. The teachers stated that they resorted to methods such as talking to the students, interviews with the parents, guidance and psychological counseling in order to fix wrong situations and to teach positive values. In addition, teachers of physical education also stated that they did not have enough information about values education. According to Kurtdede Fidan [22], information given in lessons and individual's perceptions differ and thus, problems occur. In addition, the negativity created by media in values education decreases the influence of school and teacher and while teachers have enough information about values education, they cannot be role models. Studies should be conducted to eliminate these negativities. It has been emphasized that courses and in-service trainings should be organized for employees. Examining the association between physical education and values education or the association between values education and other branches and increasing the practices in the field will provide great advantages to save future generations.

\section{REFERENCES}

[1] Gündüz, M. (2016). Classifying Values by Categories. Journal of Education and Training Studies, 4(10), 212-220.

[2] Aslan, M. (2011). İlköğretimde karakter eğitimi ve öğrencilere kazandırılması gereken değerler. Yüksek Lisans Tezi, Osmangazi Üniversitesi, Eğitim Bilimleri Enstitüsü, Eskişehir.

[3] Eser, A. (2012). Illköğretim ikinci kademe öğrencilerinin insani değerler düzeyleri ile çevresel tutumları arasındaki ilişki. Yüksek Lisans Tezi, Yeditepe Üniversitesi, Sosyal Bilimler Enstitüsü, İstanbul.

[4] TDK. (2017). Değer. Güncel Türkçe Sözlük. In 28.09.2017 Retrieved from http://www.tdk.gov.tr/index.php?option=com gts\&arama $=$ gts\&guid=TDK.GTS.59ccb8331b29a8.39390459.

[5] Trommsdorff, G., \& Chen, X. (2012). Values, Religion, and Culture in Adolescent Development. New York: Cambridge University Press.

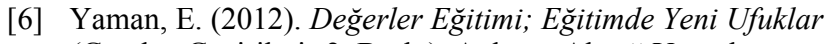
(Gözden Geçirilmiş 2. Baskı). Ankara: Akçağ Yayınları.

[7] Al-Serhan, K. A. (2015). The Degree of Adherence to Educational Values by the Students of the University of Jordan-In Their Point of View. International Education Studies, 9(1), 55.

[8] Tezcan, M. (1985). Eğitim Sosyolojisi. (4. Baskı.) Ankara: Ankara Üniversitesi Eğitim Bilimleri Fakültesi Yayınları.

[9] Kumar, S., \& Ahmad, S. (2008). Meaning, aims and process of education. In 28.09.2017 Retrieved from https://sol.du.ac.in/SOLsite/Courses/UG/StudyMaterial/16/ Part1/ED/English/SM-1.pdf.

[10] Taneja, V. R. (2008). Educational Thought and Practise. New Delhi: Sterling Publisher.

[11] Ergün, S. (2013). Ergenlere verilen değer ĕgitiminin öz düzenleme stratejileri üzerindeki etkisinin sinanmast. Yüksek Lisans Tezi, Necmettin Erbakan Üniversitesi, Eğitim Bilimleri Enstitüsü, Konya.

[12] Nguyen, Q. T. N. (2016). The Vietnamese Values System: A Blend of Oriental, Western and Socialist Values. International Education Studies, 9(12), 32.

[13] Thornberg, R., \& Oguz, E. (2013). Teachers' views on values education: A qualitative study in Sweden and Turkey. 
International Journal of Educational Research, 59(1), 49-56.

[14] Gül, R. (2013). Bir değer ĕgitimi olarak ilköğretim döneminde doğruluk eğitimi. Yüksek Lisans Tezi, Hitit Üniversitesi, Sosyal Bilimler Enstitüsü, Çorum.

[15] Berkowitz, M. W. (2011). What Works in Values Education. International Journal of Educational Research, 50, 153-158.

[16] Taylor, M. J. (2006). The development of values through the school curriculum. Values education for citizens in the new century, 107-131.

[17] Aspin, D. N., \& Chapman, J. D. (Eds.). (2007). Values education and lifelong learning: Principles, policies, programmes (Vol. 10). Springer Science \& Business Media.

[18] Beldağ, A. (2016). Values education research trends in Turkey: A content analysis. Journal of Education and Training Studies, 4(5), 101-112.

[19] Ajay Kr. (2011). Importance of physical education, games \& sports activities. VSRD Technical \& Non-Technical, 2(11), 570-573.

[20] Yıldırım, A., \& Şimșek, H. (2013). Sosyal bilimlerde nitel araştırma yöntemleri (9. Genişletilmiş Baskı). Ankara: Seçkin Yayınc1lık.

[21] Baş, T. \& Akturan, U. (2013). Nitel araștırma yöntemleri Nvivo ile nitel veri analizi. Ankara: Seçkin Yayıncılık.

[22] Kurtdede Fidan, N. (2009). Öğretmen adaylarının değer öğretimine ilişkin görüșleri. Kuramsal Eğitimbilim, 2(2), $1-18$.

[23] Balci, V., \& Erdeveciler, Ö. (2017). Some sports managers' views about values education through sports. Journal of Education and Training Studies, 5(5), 197-203.

[24] Çengelci, T., Hancı, B., \& Karaduman, H. (2013). Okul ortamında değerler eğitimi konusunda öğretmen ve öğrenci görüşleri. Değerler Ĕ̆itimi Dergisi, 11(25), 33-56.

[25] Çelikkaya, T. \& S. Filoğlu. (2014). Sosyal bilgiler öğretmenlerinin değere ve değer eğitimine ilișkin görüşleri. Kuram ve Uygulamada Eğitim Bilimleri, 14(4), 1541-1556.

[26] Yıldırım, S. G., Becerikli, S., \& Demirel, M. (2017). Farklı Bakış Açılarına Göre Sosyal Bilgiler Dersinde Değerler Eğitimi. İlköğretim Online, 16(4).

[27] Balcı, F.A. \& T. Yanpar Yelken. (2013). İlköğretim sosyal bilgiler programında yer alan değerler ve değer eğitimi uygulamaları konusunda öğretmen görüşleri. Ahi Evran Universitesi Kırșehir Eğitim Fakültesi Dergisi, 14(1), 195-213.

[28] Hadi, R. (2015). The Integration of Character Values in the Teaching of Economics: A Case of Selected High Schools in Banjarmasin. International Education Studies, 8(7), 11.

[29] Memişoğlu, H. (2013). İlköğretim 4. ve 5. sınıf öğretmenlerinin sosyal bilgiler dersinde değerler eğitimine ilişkin görüşleri. The Journal of Academic Social Science Studies, 6(3), 405-425. 